\title{
Sales coordination and structural complexity: A national-international comparison
}

\author{
Jakob Rehme, Christian Kowalkowski and Daniel Nordigården
}

\section{Linköping University Post Print}

\section{Tweet}

N.B.: When citing this work, cite the original article.

Original Publication:

Jakob Rehme, Christian Kowalkowski and Daniel Nordigården, Sales coordination and structural complexity: A national-international comparison, 2013, The journal of business \& industrial marketing, (28), 6, 514-522.

http://dx.doi.org/10.1108/JBIM-04-2013-0097

Copyright: Emerald

http://www.emeraldinsight.com/

Postprint available at: Linköping University Electronic Press

http://urn.kb.se/resolve?urn=urn:nbn:se:liu:diva-95807 
This is a so-called personal version (author's manuscript as accepted for publishing after the review process but prior to final layout and copy editing) of the article.

Rehme, J., Kowalkowski, C., \& Nordigården, D. (2013), ' Sales Coordination and Structural Complexity: A National-International Comparison ', Journal of Business \& Industrial Marketing, Vol. 28, Issue 6.

Readers are kindly asked to use the official publication in references.

\section{Sales coordination and structural complexity: A national-}

\section{international comparison}

Jakob Rehme*

Department of Management and Engineering, Linköping University, Linköping, Sweden

Christian Kowalkowski

Department of Marketing, CERS - Centre for Relationship Marketing and Service

Management, Hanken School of Economics, Helsinki, Finland

and

Department of Management and Engineering, Linköping University, Linköping, Sweden

Daniel Nordigården

Department of Management and Engineering, Linköping University, Linköping, Sweden

* Corresponding author: jakob.rehme@liu.se

\section{Brief professional biography}

Jakob Rehme is Associate Professor of Industrial Marketing at Linköping University, Sweden. Before joining academia he worked with sales management in the high-tech industry. His main research interest is sales management. He has published articles in journals such as European Journal of Marketing, International Journal of Integrated Supply Management, Journal of Forest Products Business Research, and Journal of Service Management. Jakob Rehme has taught in the areas of Marketing, Sales Management, and Industrial Economics. He can be contacted at: jakob.rehme@liu.se.

Christian Kowalkowski is Assistant Professor of Marketing at the CERS - Centre for Relationship Marketing and Service Management at Hanken School of Economics in Helsinki, Finland. He also holds a part-time position as Associate Professor of Industrial 
Marketing at Linköping University. His current research deals with service infusion in manufacturing, dynamics of value propositions, solutions marketing, and service innovation. He has published articles in journals such as European Journal of Marketing, Industrial Marketing Management, Journal of Business Research, Journal of Business \& Industrial Marketing, and Journal of Service Management. He can be contacted at: christian.kowalkowski@hanken.fi.

Daniel Nordigården is Associate Professor of Industrial Marketing at Linköping University. Before returning to academia in 2011, Daniel spent over 5 years at the global management consultant firm McKinsey \& Company Inc. His current research is focused on outsourcing, value creation, and value-added strategies. He can be contacted at: daniel.nordigarden@liu.se. 


\begin{abstract}
Purpose: The existing literature on key account management (KAM) has focused more on sales forces and management levels than on their evolution. This study explores how sales activities can be coordinated to accommodate national and international KAM programs.
\end{abstract}

Design/methodology/approach: A longitudinal study of the industrial conglomerate ABB 1996-2008.

Findings: The diversity associated with geography and product complexity creates demands for a more flexible organization that can provide a more complete offering portfolio across national boundaries and still handle the demands of local organizations. In addition to internal organizational contingencies, the key factors and driving forces for the development of KAM programs are the marketing and purchasing strategies that buyer and seller firms perceive and encounter.

Research limitations/implications: The data is limited to one corporation and some of its key customers in different industries. Although the internal and construct validity of the findings are strong, the external validity cannot be assessed precisely.

Originality/value: The 12-year study brings valuable insights to the development of KAM programs in multinational corporations and addresses coordination issues related to geographical and product complexity.

Keywords: Key account management, KAM program, sales coordination, purchasing coordination, project selling, solutions selling

Paper type: Case study 


\section{Introduction}

In response to product commoditization and competition from emerging markets, many industrial firms have started to provide complex, integrated solutions to increase value to their customers and consequently their profits (Davies et al., 2007; Galbraith, 2002; Nordin and Kowalkowski, 2010). At the same time, since mergers and acquisitions have made large firms in industrial markets even larger, large customers have also become increasingly international. This development has led to the need for more complex sales and transnational agreements, which in turn has created the need for coordination across geographical borders (Kowalkowski et al., 2011; Kucza and Gebauer, 2011; Sheth et al., 2000). Many sales professionals view such complexity as a challenge that makes selling more difficult (Brehmer and Rehme, 2009) and regard selling solutions as complexly difficult, but necessary to attain better margins (Nordin and Kowalkowski, 2010; Ulaga and Reinartz, 2011).

One way to manage these complexities is to assign a dedicated function to organizational units that are responsible for a firm's relationships with individual customers, whether national or international, and to provide these customers with comprehensive and coherent offerings (Barrett 1986; Sharma 1997). One such dedicated function is key account management (KAM), an approach in which a firm handles some customers differently from others by dedicating relevant personnel to work specifically with them. Particularly, KAM programs are organizational units that firms form to coordinate the sales effort required to serve large and complex customers (Brehmer and Rehme, 2009).

Despite KAM's relevancy for marketing and sales management, knowledge gaps occur in practice, such as which approach to KAM to employ (Homburg et al., 2002). Existing studies indicate that KAM programs involve major coordination problems (e.g., Cespedes, 1992; Millman, 1996; Shapiro and Moriarty, 1982, 1984a, 1984b). However, most studies of KAM were implemented at the sales force and management levels rather than at the KAM program level. In addition, these studies have tended to focus on KAM's static dimensions rather than its dynamic ones.

The present paper addresses these knowledge gaps by exploring and discussing how sales activities can be coordinated to accommodate national and international KAM 
programs. More specifically, it discusses the differences and similarities among the programs at the corporate level. A longitudinal study of the industrial conglomerate $\mathrm{ABB}$ was utilized to capture how KAM programs evolve over time.

\section{KAM Review}

KAM, which has developed as a concept since the 1960s (Weilbaker and Weeks, 1997), was initially a response to the challenge of managing relationships with large customers with multiple locations. The basic tenets of KAM have remained similar, and developments for both sellers and buyers have meant that the international trend towards implementing KAM has remained strong, with almost all industrial firms using the concept in one way or another (Boles et al., 1994; Weilbaker and Weeks, 1997; Brady, 2004; Nätti et al., 2006; Pardo, 2006). Homburg et al. (2000) even regarded KAM's increasing importance as one of the most fundamental changes in marketing management. Compared with other account relationships, the supplier-customer relationships in key accounts are characterized by higher supplier-specific investments, higher supplier dependence, and a higher number of actors involved on the customers' side (Ivens and Pardo, 2008).

KAM enables a firm to devote special attention to its largest and most important customers, especially when such customers comprise a substantial part of its total sales (Salojärvi et al., 2013; Stevenson and Page, 1979; Storbacka, 2012; Weilbaker and Weeks, 1997). Since these accounts make significant purchases, or at least have the potential to do so, they represent great sales opportunities, but if they already purchase substantially, they also pose a great risk (Shapiro and Moriarty, 1982; Piercy and Lane, 2006). One key reason for KAM's popularity is its ability to handle complexities by different means of coordination (Cespedes, 1992; Brehmer and Rehme, 2009). The provision of offerings must be coordinated both internally within the providers' organizations and externally by adapting to different customers' needs. This means that KAM has a role in both internal and external coordination (Shapiro and Moriarty 1982; 1984a).

The sales and marketing function is the primary sales link for external coordination between buying and selling firms. Therefore, it has a strong influence, often 
the strongest influence, on buyers' perceptions of selling organizations' offerings (cf. Weitz and Bradford, 1999). Consequently, the coordination of activities and resources between sellers and buyers is a crucial task for sales organizations if they wish to consummate the exchanges between them (Shapiro and Posner, 1976). The primary objective for KAM programs is to develop customer relationships to obtain advantages in value creation and incremental profits (Shapiro and Moriarty, 1984a; 1984b), which means that integration and coordination of buyer-seller relationships is a basic aim of KAM (Millman, 1996).

Another of KAM's functions is to coordinate a firm's internal resources, or functional units, for task completion (Ellinger, 2000). The complete offering usually consists of a set of services that are added to the core offering, making sales activities a matter of systems selling, which means offering and delivering a comprehensive package or bundle of product and service attributes and benefits (Millman, 1996). The resulting customer offering portfolio tends to be a mix of products and services produced by internal resources from such units as engineering and manufacturing that need to be coordinated if they are to meet customers' requirements. In many respects, each KAM account manager functions as the "customer's ombudsman to the company" (Shapiro and Moriarty, 1984a, p. 4), which makes internal coordination of resources imperative for account management.

\section{Research Methodology}

This paper is based on a longitudinal study that followed the industrial conglomerate ABB since 1996. The starting point for the study was to follow the empirical phenomena of key account management programs, their initiation, implementation, and management. Empirical data was collected within $\mathrm{ABB}$ and from individual key accounts as well as selected customer organizations (see Table 1).

Insert Table 1 here

The interviewees from ABB included general managers, key account managers, sales engineers, team leaders, project managers, and sales personnel. Data also was collected 
from customers in the mining, automotive, process equipment manufacturing, building technology, energy production, and telecommunication industries through interviews with purchasers and purchasing managers. Data collection, which occurred at various times between 1996 and 2008, also was described in different cases for the corresponding time period. In accordance with Eisenhardt (1989) and Yin (2003), the cases were compared for pattern matching. The analysis was made by using a replication logic approach and drawing cross case conclusions as well as mapping data to theory to compare and contrast the findings with previous studies (Eisenhardt, 1989; Yin, 2003).

\section{Coordination Through KAM: The Case of ABB}

ABB is a Swedish-Swiss corporation that manufactures power and automation products, serving a wide array of industrial customers and utilities. In 2011, ABB had approximately 134,000 employees in more than 100 countries. The company has traditionally focused on large projects, with sales to governments or large utility firms. Sales have always involved a considerable engineering component and the sales process has been predominantly project-based.

ABB's sales engineers traditionally have worked as project leaders to establish the requirements for large projects, developing agreements and sales schedules. After closing a deal, sales engineers transfer the projects to the main project managers. Prior to that point, $\mathrm{ABB}$ marketing managers, CEOs, and presidents have lobbied and networked with government authorities, politicians, and presidents for years and sometimes decades to ensure good positioning at the time that infrastructure decisions are made. Although ABB did not have a formal organization for the process, this has been ABB's KAM program up to this point.

\subsection{Requirements for Coordination and the Drivers of KAM Programs}

ABB's structure has been highly decentralized, with its separate companies acting as independent legal entities; in total, it has some 1,000 distinct companies and 5,000 profit centers (divisions). As the $\mathrm{CEO}$ for $\mathrm{ABB}$ explained:

We see ourselves as a federation of national companies with all of these local plants tied together under a country holding company. It can be 
difficult getting this across to people, this idea that we are a company with many homes. People are used to thinking of a company as a French or German or Japanese or American... (CEO Percy Barnevik, May 1996)

In many cases, this decentralization has been beneficial for the individual companies (cf. Bartlett and Ghoshal, 1993), focusing their production and logistics processes. Furthermore, ABB's individual companies have benefited from relatively increased proximity to their respective markets and the structure has allowed for fewer layers of managers and less distance between customers and production.

The individual ABB companies became more efficient and customer-focused in their independence. Other than the top corporate managers, however, the structure lacked coordinators who focused on the corporation's interests. Product development coordination, for instance, was oriented toward the different business areas. The predominant coordination mechanism in this structure was business area managers and cross-company boards, which included managing directors from other $\mathrm{ABB}$ companies as well as business area managers.

This decentralized organizational structure resulted in an increased differentiation, with the development of new products and the alteration of existing ones occurring in isolation in each company. This was expected because the individual companies had the market and production information that was necessary for efficient product development and sales and marketing management. These separate units were well equipped to deal with product development, thanks to their focus on their particular products and their specific manufacturing processes and markets. However, ABB had no clear mission regarding coordinating the individual business areas' product development effects, or making its products more closely related and interdependent. At the same time, customers perceived $\mathrm{ABB}$ as one entity. However, since the separate companies experienced considerable decentralized decision-making, customers were not dealing with one corporation, but rather with an entire group of suppliers. In particular, when a problem arose, the customer did not consider it to be an ABB company (for example, ABB Motors or $\mathrm{ABB}$ Kraft) problem, but rather an $\mathrm{ABB}$ problem. As one $\mathrm{ABB}$ sales engineer said: 
[The customers] do not consider if it is Industrial Systems or Motors or someone else, it is $A B B$. We noticed this constantly. Particularly when there is some sort of controversy, the customer does not care whether it is Industrial Systems, Motors, or Installation who is to blame; it is an ABB problem. [And the customer says] "solve this"... (Sales Engineer) ABB's companies and divisions had developed from highly interdependent to increasingly independent. With the group's track record of multiple acquisitions and consolidations, this was hardly surprising, as the corporate managers had divided the different areas of product responsibility and expertise among the various companies and grouped them together into business areas. More coordination than before had developed within the business areas regarding product sales and product development. The CEO for $\mathrm{ABB}$ described it this way:

...We have global business areas for particular products, such as transformers or motors. Each has a management team with global overview, deciding if we should put a motor plant in Shanghai or not, who will produce and develop what, who should export to what market.

Each business area sets the world charter for that particular product. Otherwise, local business would run into each other and there would be chaos out in the market. (CEO Percy Barnevik, May 1996)

This area coordination may have been caused by the inherent coordinating mechanism of the sales force, since one sales engineer was responsible for the production of all or part of one business area; in other words, the sales engineers or their customers, rather than just the business managers, were driving this. In effect, sales engineers functioned as permanent coordination teams for each business area (cf. Galbraith, 1973; 2002).

Accordingly, coordinating sales efforts across business area boundaries prompted coordination of technological and product development on the ABB group level. One of these changes was evident in an early $\mathrm{ABB}$ reorganization in which regions and business areas rose in importance within the organization. This was particularly evident for larger projects with multiple business areas and multisegment and multinational involvement (cf. Berggren, 1996). 
However, the coordination of product sales and product development, particularly across business areas, was still in its infancy. ABB's product portfolio had developed over many decades, whereas its organizational structure had developed only for approximately 10 years. Many highly related and even functionally interdependent products experienced minimal cross-company cooperation in terms of sales and development. This constituted unfulfilled potential interdependence (see Lorsch and Allen, 1973) among different entities, leaving untaken a latent opportunity for coordinating product offerings into a more comprehensive corporate offering.

However, ABB's decentralized sales organization's structure must be divided into units with two separate functions, one for the sale of products and systems and one for the sale of projects. Traditionally, ABB's core activity has been producing and administering large projects. Project selling has inherent characteristics aimed at coordinating activities for task completion (Bonaccorsi et al., 1996), and is usually formalized with schedules and plans for activities conducted by a group (cf. Galbraith, 1973; Joyce et al., 1997). $\mathrm{ABB}$ coordinated international cooperation and cross-company activities through such project groups, particularly for large-scale projects (cf. Berggren, 1996), but had little or no formal structure for coordinating product and system selling. The organization was separated into country sales companies, with sales engineers representing one business area and product managers covering individual product lines.

This decentralized organization was not primarily a response to diversity in market requirements; instead, it was a way to organize the corporation internally to achieve individual customer commitment and efficiency in operations. Therefore, the corporation's restructuring can be seen as a reaction to the need to become more marketoriented by managing the diversity in its environment. This diversity is based on differences in customer size, which make it more important to take care of large customers primarily through KAM programs. There is also diversity between industries, which has led to a belief within ABB's management that stronger interdependence exists within industry segments than between related products intended for the general market. 


\subsection{ABB's Development of KAM Programs}

As ABB's decentralized organizational structure became detrimental to coordinated sales and marketing operations, a need arose for a formal structure to handle larger customers. In 1996, ABB Sweden formed the Swedish Market program, which consisted of the Swedish ABB companies and their sales organizations. The focus of the approach was to create easy contact for individual customers. The Swedish Market program was a management initiative, as the managing director explained:

... to try to make the relationship with the customer as simple as possible. This is the essential idea with the ABB Swedish Market program ... (Managing Director for ABB Sweden)

One of the most important reasons for starting the program was the need for a solution to ABB's complicated internal structure, as corporate management had become aware that ABB's customers sought a more coordinated business partner. Management also saw the coordination as a proactive opportunity to develop more coordinated and, consequently, more comprehensive offerings for their customers. In strategic terms, the ABB Swedish Market's development and current task was expressed as:

Our task is to move towards a more coordinated ABB, a network, whose primary task is to simplify for the customer, and help customers with total solutions, without changing the good things in our decentralized organization. (ABB internal material translated)

The program's level in itself made up another dimension in the matrix cutting across business areas within ABB's Sweden organization. It was specifically aimed at supporting the KAM teams that acted as the actual coordination units. The international sales coordination effort sought to benefit from ABB's international knowledge of sales management and to follow its customers' internationalization by accommodating international agreements and large customers' continuing consolidation.

ABB's KAM programs were answers to the requirements that the organizational structure had placed on the sales organization. The Swedish Market program developed with a focus on country organization. The KAM teams provided the coordination between ABB's different divisions or business areas. When the business areas increased in importance, their interest in the Swedish Market program decreased. Although the 
business areas were originally committed to the Swedish Market program, it appears as though they had difficulty maintaining that interest when top management refocused on them.

The business areas' international sales organizations were subjected to customer pressure requiring them to coordinate internationally. Initially, $\mathrm{ABB}$ did not respond by implementing KAM programs for these customers, but instead used sales engineers and managers as coordinators or persuaders to deal with companies within their business areas. But before long, ABB organized formal KAM groups to interact with customers on an international basis. However, the international KAM groups (iKAMs) still have little formal authority, and instead, must earn the trust of participating business area companies. The KAM programs' organizational structure was completed with international and national KAM groups assigned to each individual account. This structure was an answer to the geographical structure in the matrix (cf. Galbraith, 1995) in which iKAMs held global responsibilities resembling centers of excellence.

In effect, these two programs involved the integration of product and geographic differentiation issues in the matrix structure. Geographic differentiation is necessary to be close to customers and to divide a corporation into manageable product divisions to achieve product specialization. The resulting matrix structure resembles what Galbraith $(1995 ; 2002)$ defined as a front-end/back-end structure, with the front-end responsible for sales and marketing in the geographical structure and the back-end responsible for products. The sales and marketing organization, or the front-end of $\mathrm{ABB}$, includes its country sales companies and regional sales offices. To some extent, the front-end units coordinate the product offerings to their markets, but each within only one business area.

Prior to the creation of the KAM programs, the dispersion of customer locations and the differentiation and specialization among divisions was not an internal problem, as each unit was able to act individually. But with the introduction of KAM to the Swedish Market program and with international customer requirements, a need arose for coordination across divisions. In the Swedish Market program, KAM coordination and the desire to provide a coordinated offering made the different product divisions interdependent. In the international program, striving for international coherence among sales companies was the key factor that led to geographical interdependence among sales 
units. Therefore, the predominant function of the KAM programs has been to coordinate the interdependence between geographical units and product divisions. The two KAM programs functioned as structures layered into the matrix, adding a customer-centered dimension to the product and geographical location matrix (cf. Shapiro and Moriarty, 1982).

Figure 1 depicts the three ABB KAM programs and their differences in overall organizational development. The Swedish Market program (1) designed its KAM using a team approach, which coordinated business areas and segments to develop more coherent offerings for key customers. Full-time marketing directors were responsible for managing, deploying, and following up on the program. One group director had overall responsibility, with three marketing managers geographically dispersed to manage operations in the different Swedish regions. In this case, the complexity stemmed primarily from the coordination of product or system offerings.

Insert Figure 1 here

A CEO from an ABB company headed the business area's international sales coordination of the international program (2) on a part-time basis, acting jointly with the business area's management to oversee a number of task forces staffed with sales managers from both export and domestic sales. Program coordination was predominantly conducted through meetings with business area managers, export sales managers, and domestic sales managers from Europe and the United States. The program primarily achieved international business area sales coordination via information diffusion and information sharing on a reciprocal basis.

The complexity originated mainly from geographical coordination, as customers wanted international treatment to various extents. Obviously, elements of technical and product coordination were also present in these cases, but to a less complex degree, as their coordination was restricted to one business area. Some KAM cases also addressed both issues simultaneously. They usually started off as national KAM programs, although working with these customers intensified when they moved toward more international content. 
These operations later escalated into a global KAM program (3) with an explicit market structure, their coordination mechanisms appearing to be more reliant on the corporate hierarchy, with multiple business areas and a high reliance on international compliance. Thus, ABB has defined 30 global accounts with executive sponsors from top corporate management who chose these accounts because they were global in scope and had potential to create broader offerings that include several divisions and business units, which they termed "cross-ABB portfolio opportunities."

According to ABB managers interviewed for this study, the benefits of the account programs included (a) early identification of project opportunities, trends, and market drivers, (b) increased visibility of cross-business opportunities and higher valueadded offerings, and (c) allowing key customers to have a stake in ABB technology development, lifecycle support, and industry-specific solutions. As one sales engineer said:

You have gone from the large organization where everybody has worked in the same "pie" towards the market. Then this pie has been divided into slices or islands, and then these islands have gone their separate ways and lived their separate lives. Now we are trying to bring them back together again. (Sales Engineer)

Table 2 outlines the organizational development and corresponding KAM and market structures.

Insert Table 2 here

\subsection{Buyer Context and Drivers for KAM Programs}

Individual customer situations are an important driver in such customer-oriented situations as KAM programs. ABB's corporate management viewed the organizational development of customers as one of the most important reasons for KAM development, primarily because management felt that industry consolidations were making customers larger and more complex, spanning larger regions and with operations in multiple locations in various countries and having needs for diverse sets of products and systems. 
Both the Swedish Market and the International programs involved customers with plants in multiple locations. Their structures included production companies located across Europe and the United States, and the Swedish Market program's customers normally operated at multiple locations in Sweden. The programs' managers perceived that consolidating customers involved massive coordination problems for the purchasing organizations, particularly when they needed to engage in centralized actions. More complex purchasing requires buying centers and coordination among internal functions as well as among units (Dawes et al., 1998; Morris et al., 1999; Sharma, 1997).

$\mathrm{ABB}$ did not completely analyze the issue of centralization versus decentralization in purchasing from the sellers' perspective, but evaluated the fit between KAM structures and purchasing organizations primarily from the perspective that the customers were interested in more comprehensive offerings and that they were moving towards corporate purchasing, either by centralizing or coordinating the purchasing process. Specific projects aimed particularly at coordinating the purchasing for the corporate entity as a whole started to emerge, which basically meant that both buyers and sellers were approaching the same types of solutions, albeit from opposite directions: the coordination of sales and the coordination of purchasing.

Although the formation of KAM programs assumes the need for some centralization or coordination in customer purchasing operations, and although KAM programs are believed to benefit from centralized or coordinated purchasing (Barrett, 1986; Pardo, 1997), the interviewees for this study continued to believe that the majority of interactions would be handled locally. Consequently, decentralized purchasing operations constitute a barrier to efficient KAM operations. Although a structural fit between seller and buyer is vital for retaining relationships (Mattsson and Björkroth, 1978), the major factor determining the initiation of ABB's KAM programs was that customers were becoming larger. For example, for the Swedish sales organization, the top 100 customers accounted for almost 80 percent of the total sales. With such an asymmetric customer base, there is obviously a tendency to prioritize the larger customers over the small. The fact that individual KAM cases in this study had relatively decentralized organizational purchasing structures indicates that this was so. 
The decentralized structures also complicated the KAM programs' ability to complete tasks. However, when one of ABB's major customers started coordinating its purchasing operations for some ABB products, the KAM program worked more efficiently. The centralization or decentralization of purchasing is closely associated with purchasing strategy and may be determined differently based on the types of organizational offerings involved. Furthermore, although those involved viewed general agreement as a central issue for customers' purchasing, they did not view task completion in the same way.

\subsection{The Buyer-Seller Context and Drivers: A Comparison}

Despite the large amount of continued discussion regarding customer focus and pursuing customer-centered marketing, there are still large discrepancies between marketing strategies and how buying companies perceive their own roles. While buyers focus on cost reductions, sales organizations primarily focus on increased sales. Therefore, reducing the total costs in a relationship is not a marketing strategy's first priority.

Price is sometimes difficult for us ... But we have other strengths - our tradition, our technology, the quality, the [geographical] closeness - all these things are very important, as [the customer] Svedala Arbrå confirms. (Team Leader)

In the Swedish Market situation, $\mathrm{ABB}$ had been pursuing coordination prior to any specific customer demand to do so. This is a clear indication that this particular ABB sales organization was, in some respects, leading the way for these approaches and had actually created the prerequisites for altering some of their customers' ways of buying products. We do not argue that the customers' tendency to start up coordination projects for some of their purchasing was directly linked to ABB's initiating KAM programs, but rather that these programs simply preceded the efforts of these customers' buying organizations to coordinate purchases among different units.

The international KAM program's situation was somewhat different. ABB's customers' impetus for this program was relatively strong, and some of the relationships that constituted the reason for the program's initiation involved elements in which the customers placed coordination requirements on ABB's organizational agenda. This meant that its customers' organizations induced a more integrated way for ABB to organize its sales organization. Therefore, the dedication to purchasing coordination among the 
customers' organizations resulted in more ABB sales coordination through its KAM program. Furthermore, instances involving joint action in the formation of KAM programs also appear to have involved joint efforts to achieve coordination. The rationale for moving toward more sales coordination when a customers' organization is coordinated is much stronger then when sales coordination is what influences purchasing (see Figure 2).

Insert Figure 2 here

As Figure 2 illustrates, low levels of purchasing and sales coordination constitute the starting point of this study. Both ABB and its customers were large and highly divisionalized organizations, with neither purchasing nor sales coordinated to any great extent. Initially, such practices fitted well within the relationships, as both of these functions were specialized and relatively narrow.

\section{Towards a Model for KAM Programs}

Two basic, interrelated driving forces are behind the formation of KAM programs - the development of marketing and purchasing strategies and the structural situations of the corporations concerned (Chandler, 1998). For instance, industry consolidation, which makes large customers larger, heightens the need and importance of trying to attain market share, and marketing strategies aimed at pursuing systems selling and international selling are a logical result of this. Industry consolidation also makes purchasing coordination important for buyers, as larger organizations can achieve purchasing clout and greater standardization of inputs and systems within their corporations and can also better coordinate procurement, making purchasing processes leaner (see Figure 3).

In ABB's organizational development, specialization into product groups resulted in a product divisional structure, and therefore, more differentiation among business areas. This divisionalization resulted in less interdependence among units and has made integration more difficult. However, specialization within product groups resulted in higher differentiation among them - and therefore, among business areas - but it also 
resulted in customer-dedicated sales personnel with responsibility over these product groups. Therefore, this differentiation has addressed the complexities within sales operations, underlining the perception within $\mathrm{ABB}$ of the importance of technical capabilities for such operations.

Insert Figure 3 here

Although ABB's organizational structures prior to initiating KAM programs were detrimental to interdepartmental integration, they did reveal the need for coordination to attain a more integrated organization, particularly since both the marketing and purchasing strategies directed corporate operations toward a more integrated sales organization. Organizational theorists such as Lorsch and Allen (1973) and Lawrence and Lorsch (1969) have defined organizational structures as being largely dependent on environmental conditions, which means that these structures are based on the adaptations that organizations make to market situations (Werther, 1999). However, large organizations such as $\mathrm{ABB}$ are unable to adapt quickly enough to individual customer requirements, which can be vitally necessary in order to effectively serve large customers. ABB's KAM organizations are highly dependent on market situations and are themselves market adaptations at the organization's front end that do not require the entire organization to be restructured.

\section{Conclusion}

This study has made four main contributions to understanding KAM programs. First, it is essential to make a general distinction between the KAM program level and the dyadic KAM relationship and, therefore, of the connection between the programs and individual key accounts. Second, the way in which KAM programs, as structural overlays within organizations, affect organizational structures is prevalent for both multimarket and multiproduct KAM programs. Third, KAM can affect the sales and marketing interface by greatly expanding customer offerings. Finally, the study found that KAM programs could evolve as both reactive and proactive strategic responses. 
$\mathrm{ABB}$ has long been solutions-oriented for large-scale projects, with a high degree of coordination capability and dedication without formal back-end resource control. The KAM programs this study analyzed underlined the organization's adaptability toward individual repeat customers. Furthermore, from an organizational perspective, diversification and integration relate to the two structural poles of centralization and decentralization, between which organizations appear to vacillate (Ghoshal and Mintzberg, 1994).

The ABB personnel interviewed for this study tended to perceive that large customers must be dealt with by an integrated $\mathrm{ABB}$ organization, yet they still preferred a decentralized, diversified corporate structure. Therefore, the KAM programs may be viewed as organizational entities that coordinate the $\mathrm{ABB}$ organization into a seemingly integrated whole without actually integrating its units. This means that these KAM programs are overlayered, customer-oriented, organizational coordination formations, which expands Shapiro and Moriarty's (1984a) description of KAM programs as passive organizations in existing structures to forms that affect those structures.

Diverse markets, with the demands of large and small customers, multiple geographic locations, and a wide range of product diversity create a demand for more flexible organizations that can provide more complete product portfolios across national boundaries and still handle local customers' demands. Large customers have demands that include these issues; they require a wide range of products and systems that can be provided internationally and they also require adaptation to local needs.

Those interviewed for this study from ABB perceived these local needs to be decreasing, although their customers were pursuing coordinated actions to standardize incoming components while still demanding a high level of local operational activity. Therefore, the KAM programs appeared to be reactions to accommodate particular customer demands. The power relationships within $\mathrm{ABB}$ either could be the result of such external forces as customer demand and market shifts that have altered the organization's power patterns or could be based solely on existing internal power situations in the ABB management hierarchy.

In addition to firms' organizational contingencies, the factors and driving forces affecting the development of KAM programs are the marketing and purchasing strategies 
that firms engaged in mutual transactions perceive and encounter. ABB's marketing strategies focused on complex offerings, international sales, and market share. Similarly, its purchasing strategies included the national and international coordination of corporate purchasing and a degree of functional buying. This also means that marketing and purchasing strategies were important reasons for establishing KAM programs.

However, coordinated purchasing and selling may be perceived both as an issue of organizational structure and of the strategy for how to direct purchasing and selling activities. This phenomenon addresses long-debated issues of strategy and structure and their effects on firms (Chandler, 1962; 1998; Harris and Ruefli, 2000; Koehler, 1990). A firm's structure strongly affects its ability to coordinate, while strategy directs coordination efforts. Chandler (1998) found that "structure ... had as much impact on strategy as strategy had on structure" (p. 348), even though strategy comes chronologically before structure.

Whether coordinated selling or purchasing is more related to structure than to strategy is difficult to discern, but ABB's top management had strategic considerations in distributing power to different dimensions in the matrix, thereby establishing a new pattern of organizational power relationships. And this structure fully enabled the implementation of the coordinated KAM sales and marketing strategies.

The strategic and structural fit between buyers and sellers in the different KAM programs is particularly interesting, especially in respect to the actions and reactions toward coordination of those involved. The buyers' actions in coordinating purchasing resulted in sales coordination, and therefore, the KAM programs' gaining considerable importance, while solely seller-initiated KAM programs entailed more organizational adaptations by the seller. Therefore, it appears more difficult to persuade buyers to coordinate their operations on the basis of the sellers' interests.

Furthermore, in a seller-reactive strategy, KAM programs are under more compulsion to do the coordinating and, therefore, are more focused in their efforts. With a proactive strategy, coordination efforts are less defined and, at least initially, need to have a larger scope. Finally, although KAM programs' seller strategies are directed toward selling more by being the preferred or sole supplier (Barrett, 1986; Shapiro and 
Moriarty, 1982), buyer strategies usually are aimed at cost reductions by developing closer supplier relationships (Dwyer et al., 1987; Kalwani and Narayandas, 1995).

\section{References}

Barham, K. and Heimer, C. (1998), ABB The Dancing Giant: Creating the globally connected corporation. London, Financial Times - Pitman Publishing.

Barrett, J. (1986), "Why Major Account Selling Works", Industrial Marketing Management, Vol. 15 (February), pp. 63-73.

Bartlett, C.A. and Ghoshal, S. (1993), "Beyond the M-form: Toward a Managerial Theory of the Firm", Strategic Management Journal, Vol. 14 (Winter), pp. 2346.

Berggren, C. (1996), "Building a Truly Global Organization? ABB and the problems of integrating a multi-domestic enterprise", Scandinavian Journal of Management, Vol. 12 No. 2, pp. 123-137.

Boles, J.S., Pilling, B.K. and Goodwyn, G.W. (1994), "Revitalizing Your National Account Marketing Program: The NAM Audit", Journal of Business \& Industrial Marketing, Vol. 9 No. 1, 24-33.

Bonaccorsi, A., Pammolli, F. and Tani, S. (1996), "The Changing Boundaries of System Companies", International Business Review, Vol. 5 No. 6, pp. 539-560.

Brady, N. (2004), "In search of market orientation - An experiment in Key Account Management”, Marketing Intelligence and Planning, Vol. 22 No. 2, pp. 144-59.

Brehmer, P.O. and Rehme, J. (2009). "Proactive and reactive: drivers for key account management programmes", European Journal of Marketing, Vol. 43 No. 7-8, pp. 961-984.

Cespedes, F.V. (1992), "Sales Coordination: An Exploratory Study", Journal of Personal Selling \& Sales Management, Vol. 12 (Summer), pp. 13-29.

Chandler, A.D. (1962), Strategy and Structure, MIT Press, Cambridge, MA.

Chandler, A.D. (1998), "Corporate Strategy and Structure: Some Current Considerations", Society, Vol. 35 No. 2, pp. 347-350.

Davies, A., Brady, T. and Hobday, M. (2007), "Organizing for solutions: Systems seller vs. systems integrator", Industrial Marketing Management, Vol. 36 No. 2, pp. $183-93$.

Dawes, P.L., Lee, D.Y. and Dowling, G.R. (1998), "Information Control and Influence in Emergent Buying Centers”, Journal of Marketing, Vol. 62 (July), pp. 55-68. 
Dyer, J., Kale, P., and Singh, H., (2001), "How to make strategic alliances work", MIT Sloan Management Review, Vol. 42 No. 4, pp. 37-43.

Dwyer, F.R., Schurr, P.H. and Oh, S. (1987), "Developing Buyer-Seller Relationships", Journal of Marketing, Vol. 51 (April), pp. 11-27.

Ellinger, A.E. (2000), "Improving Marketing/Logistics Cross-Functional Collaboration in the Supply Chain”, Industrial Marketing Management, Vol. 29 No. 1, pp. 85-96.

Eisenhardt, K. (1989), "Building Theories from case study research", Academy of Management Review, Vol. 14 No. 4, pp. 532-550.

Galbraith, J.R. (1973), Designing Complex Organizations, Addison-Wesley, Reading, MA.

Galbraith, J.R. (1995), Designing Organizations. An Executive Briefing on Strategy, Structure and Process. Jossey-Bass Publishers, San Francsisco.

Galbraith, J.R. (2002), “Organizing to Deliver Solutions", Organizational Dynamics, Vol. 31 No. 2, pp 194-207.

Ghoshal, S. and Mintzberg, H. (1994), "Diversifiction and Diversifact", California Management Review, Vol. 37 (Fall), pp. 8-27.

Harris, I.C. and Ruefli, T.W. (2000), "The Strategy/Structure Debate: An Examination of the Performance Implications", Journal of Management Studies, Vol. 37 No. 4, pp. 587-603.

Homburg, C., Workman, J.R. Jr., and Jensen, O. (2000), "Fundamental changes in marketing organization: The movement toward a customer-focused organizational structure", Journal of the Academy of Marketing Science, Vol. 28 No. 4, pp. 459-78.

Homburg, C., Workman, J.P. Jr., and Jensen, J. (2002), “A configurational perspective on key account management", Journal of Marketing, Vol. 66 No. 2, pp. 38-60.

Ivens, B.S. and Pardo, C. (2008), "Key-account-management in business markets: an empirical test of common assumptions", Journal of Business \& Industrial Marketing, Vol. 23 No. 5, pp. 301-10.

Kale, P., Dyer, J.H., and Singh, H. (2002), “Alliance Capability, Stock Market Response, and Long Term Alliance Success: The Role of the Alliance Function", Strategic Management Journal, Vol. 23 No. 8, p. 747.

Kalwani, M.U. and Narayandas N. (1995), "Long-Term Manufacturer-Supplier Relationships: Do They Pay Off for Supplier Firms?” Journal of Marketing, Vol. 59 (Jan), pp. 1-16.

Koehler, K.G. (1990), "Fit the structure to the strategy", CMA Magazine, Vol. 64 No. 7, p. 17. 
Kowalkowski, C., Kindström, D., and Brehmer, P-O. (2011), "Managing industrial service offerings in global business markets", Journal of Business \& Industrial Marketing, Vol. 26 No. 3, pp. 181-192.

Kucza, G. and H. Gebauer, (2011) "Global approaches to the service business in manufacturing companies", Journal of Business \& Industrial Marketing, Vol. 26 No. 7, pp. 472 - 483

Lawrence, P.R. and Lorsch, J.W. (1969), Developing Organizations: Diagnosis and Action, Addison-Wesley, Reading, MA.

Lorsch, J.W. and Allen, S.A. (1973), Managing Diversity and Interdependence: An organizational Study of Multidivisional Firms, Harvard Business School/Division of Research, Boston.

Mattsson, L-G. and Björkroth, G. (1978), "Varför byter man leverantör - och varför inte?”, in Håkansson, H. and Melin, L. (Eds.), Inköp, P.A. Norstedt \& Söners förlag, Stockholm, pp. 55-72.

Millman, T. (1996), "Global Key Account Management and Systems Selling”, International Business Review, Vol. 5 No. 6, pp. 631-645.

Mohr, J. and Nevin, J.R. (1990), "Communication Strategies in Marketing Channels: A Theoretical Perspective”, Journal of Marketing, Vol. 54 (October), pp. 36-51.

Morris, M.H., Berthon, P. and Pitt, L.F. (1999), "Assessing the Structure of Industrial Buying Centers with Multivariate Tools", Industrial Marketing Management, Vol. 28, pp. 263-276.

Nätti, S., Halinen, A. and Hanttu, N. (2006), "Customer knowledge transfer and key account management in professional service organizations", International Journal of Service Industry Management, Vol. 17 No. 4, pp. 304-19.

Nordin, F., and Kowalkowski, C. (2010), "Solutions offerings: a critical review and reconceptualization", Journal of Service Management, Vol. 21 No. 4, pp. 441459.

Pardo, C. (1997), "Key account management in the business to business field: the key account's point of view", Journal of Personal Selling \& Sales Management, Vol. 17 No. 4, pp. 17-26.

Pardo, C. (2006), "Key account management in the industrial field”, in Sarathy, V.P. and Balakhrishna, A.V. (Eds.), Key Account Management: Concepts and Applications, ICFAI University Press. Hyderabad, India.

Piercy, N. and Lane, N. (2006), "The Underlying Vulnerabilities in Key Account Management Strategies", European Management Journal, Vol. 24 No. 2-3, $151-62$. 
Poppo, L. (1995), “Influence Activities and Strategic Coordination: Two Distinctions of Internal and External Markets", Management Science, Vol. 41 (December), pp. 1845-1859.

Salojärvi, H., Saarenketo, S., and Puumalainen, K. (2013) "How customer knowledge dissemination links to KAM”, Journal of Business \& Industrial Marketing, Vol. 28 No. 5.

Shapiro, B.P. and Moriarty, R.T. (1982), National Account Management: Emerging Insights, Working paper. Marketing Science Institute, Cambridge, MA.

Shapiro, B.P. and Moriarty, R.T. (1984a), Organizing the national account force. Working paper. Harvard University, Boston.

Shapiro, B.P. and Moriarty (1984b), Support systems for national account management programs: Promises made, promises unkept. Working paper. Harvard University, Cambridge, MA.

Shapiro, B.P. and Posner, R.S. (1976), "Making the major sale", Harvard Business Review, 54 (March/April), pp. 68-78.

Sharma, A. (1997), "Who Prefers Key Account Management Programs? An Investigation of Business Buying Behavior and Buying Firm Characteristics", Journal of Personal Selling \& Sales Management, Vol. 17 (Fall), pp. 27-39.

Sheth, J.N., Sisodia, R.S. and Sharma, A. (2000), "The Antecedents an Consequences of Customer-Centric Marketing", Journal of the Academy of Marketing Science, Vol. 28 (Winter) pp. 55-66.

Stevenson, T.H. and Page (1979), "The adoption of national account marketing by industrial firms", Industrial Marketing Management, Vol. 8 No. 1, pp. 94-100.

Storbacka, K. (2012), "Strategic account management programs: Alignment of design elements and management practices", Journal of Business \& Industrial Marketing, Vol. 27 No. 4, pp. 259-274.

Ulaga, W. and Reinartz, W.J. (2011). "Hybrid offerings: how manufacturing firms combine goods and services successfully", Journal of Marketing, Vol. 75 (November), pp. 5-23.

Werther, W. (1999), "Structure-Driven Strategy and Virtual Organization Design", Business Horizons, Vol. 42 No. 2, pp. 13-18.

Weilbaker, D. and Weeks (1997), "The Evolution of National Account Management: A Literature Perspective", Journal of Personal Selling \& Sales Management, Vol. 17 (Fall), 49-59. 
Weitz, B.A. and Bradford, K.D. (1999), "Personal Selling and Sales Management: A Relationship Marketing Perspective", Journal of the Academy of Marketing Science, Vol. 27 (Spring), pp. 241-254.

Yin, R. (2003), Case Study Research: Design and Methods, Sage, Thousand Oaks. 
Table 1. Data Collection.

KAM program Interviews Meetings

\begin{tabular}{lll} 
ABB Swedish Market & 20 & 9 \\
International Coordination (IPS) & 12 & 18 \\
ABB Global Accounts & 17 & 7 \\
\hline
\end{tabular}


Table 2. Organizational and program development: An overview.

$\begin{array}{lll}\text { KAM program } & \begin{array}{l}\text { Formal organizational Program structure } \\ \text { structure }\end{array}\end{array}$

Swedish Market Matrix with geographic and product divisions. Country organization with relatively high power.

Matrix with geographic and product divisions. Business area with relatively high power.
Matrix without formal authority. Regions and customer segment structure. Sales teams cross-business area.

International key account managers and national account managers. Division into market segments for knowledge sharing.
Coordination mechanisms
Based on commitment and meetings.

Customer-facing coordination conducted by KAM teams.

Management commitment and meetings. Customer commitment by mutual information sharing and occasional meetings. 


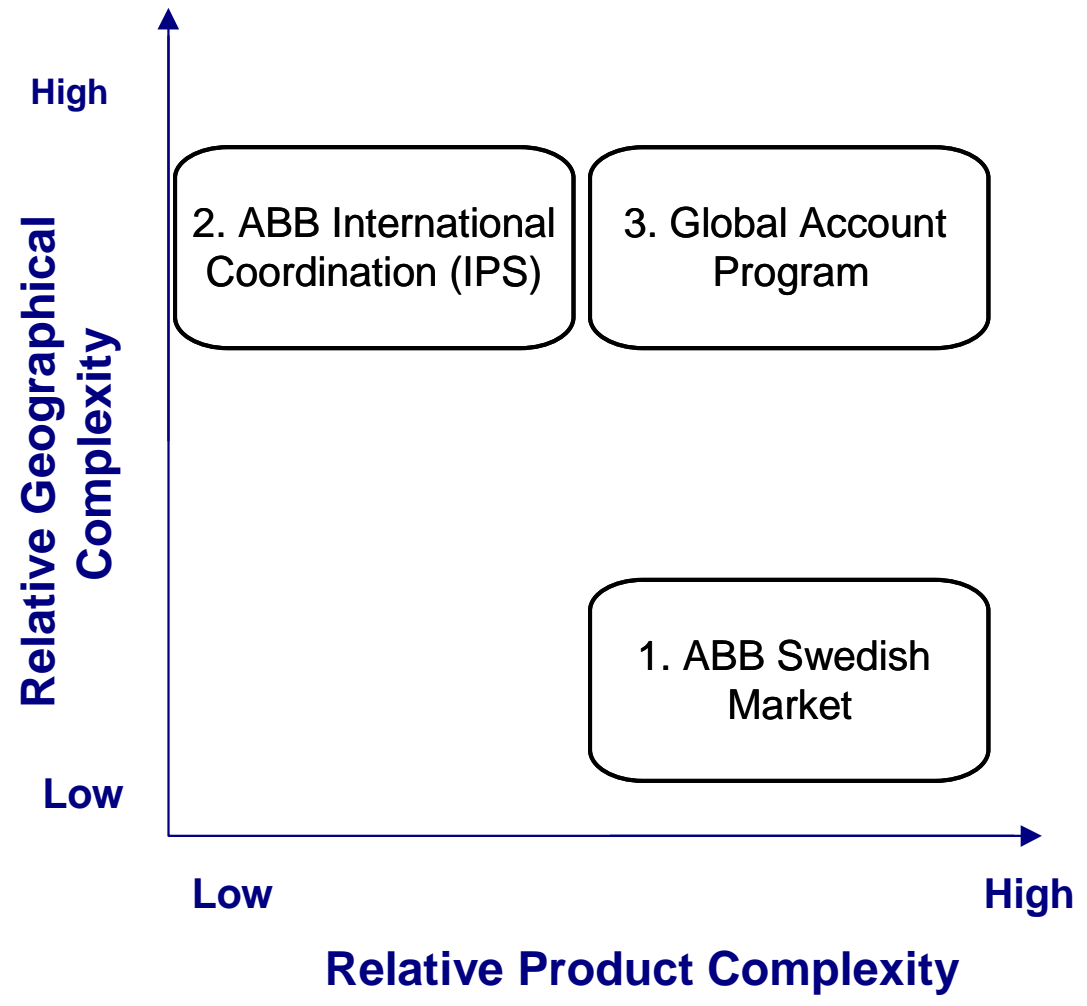

Figure 1. The development of three different ABB KAM programs. 


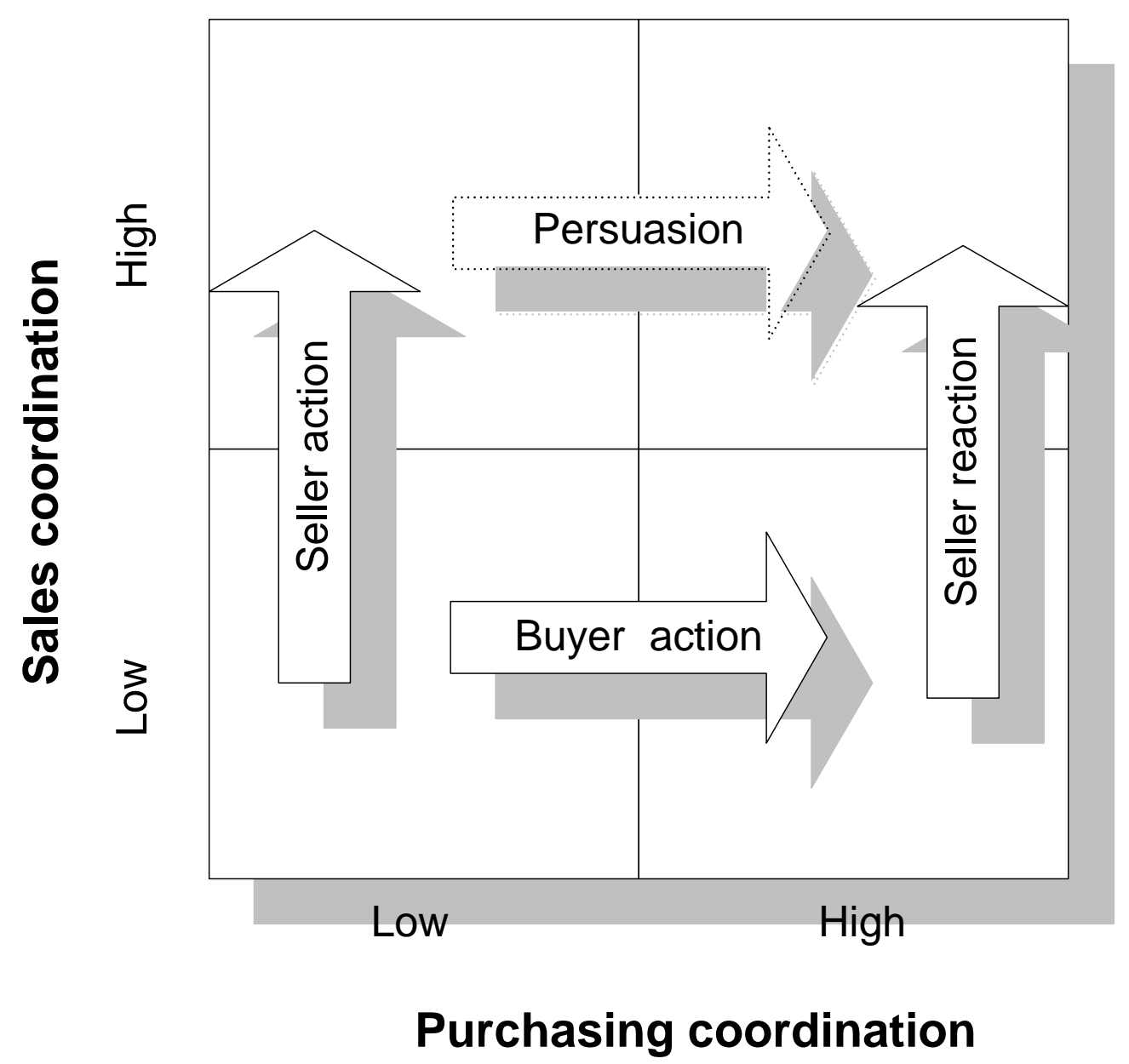

Figure 2. The development of sales and purchasing coordination. 


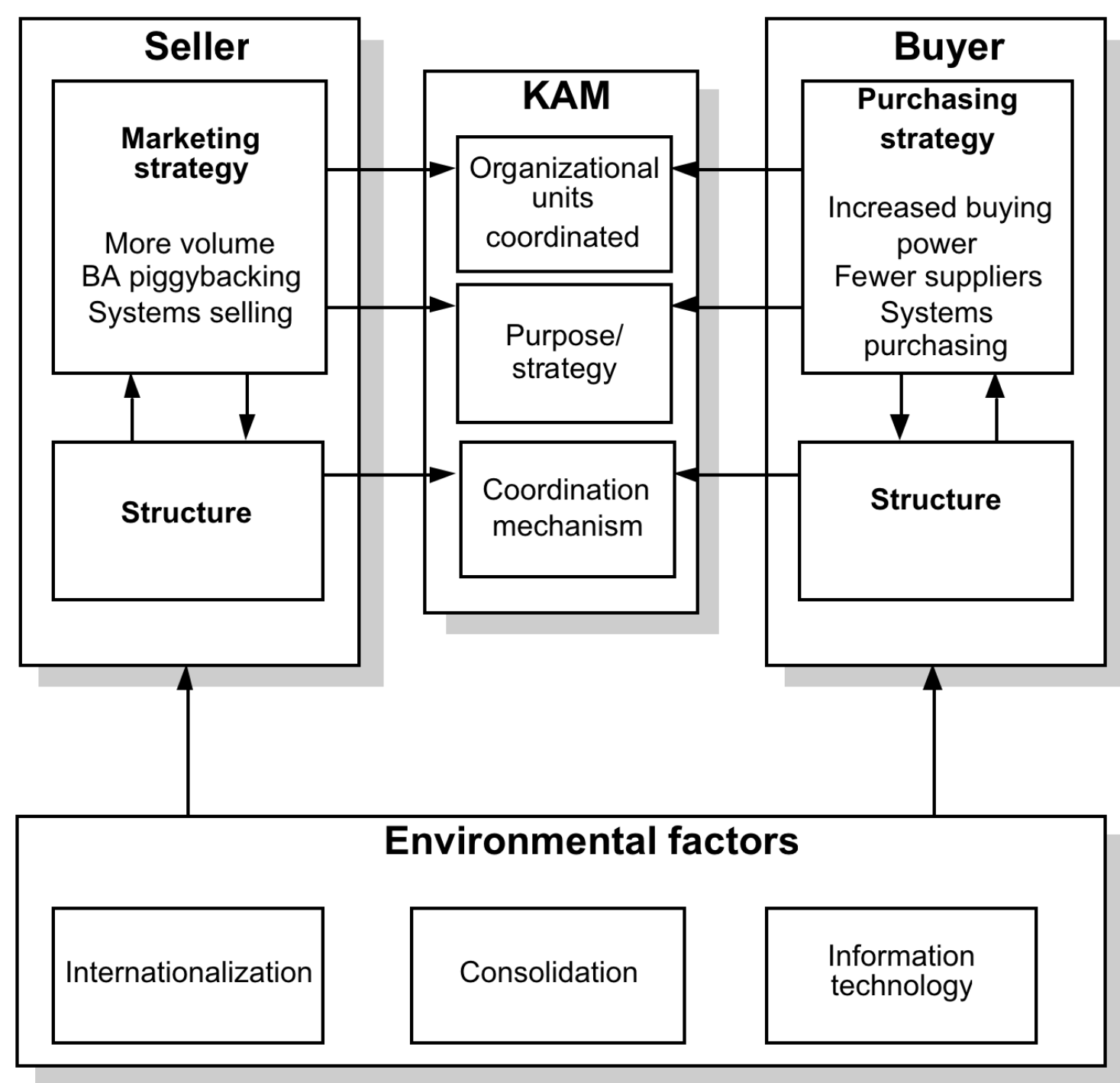

Figure 3. Model for the development of KAM programs. 